\title{
Protein EMSY
}

National Cancer Institute

\section{Source}

National Cancer Institute. Protein EMSY. NCI Thesaurus. Code C111828.

Protein EMSY (1322 aa, $141 \mathrm{kDa}$ ) is encoded by the human EMSY gene. This protein is involved in transcription repression and may be involved in DNA repair. 